\title{
A NEWLY DISCOVERED MITHRAEUM AT OSTIA ${ }^{1}$
}

\begin{abstract}
Summary: In 2014, during the archaeological investigations carried out by the University of Bologna (Department of History and Cultures - Section of Archaeology), within the Ostia Marina Project, in the suburban neighborhood out of Porta Marina (block IV, ix), a new building has been found with outstanding Mithraic features. The building, for the special type of the marble floor of the spelaeum, has been conventionally called the "Mithraeum of colored marbles". The spelaeum has a single bench, a ritual well and a flowerbed for a sacred plant. It differs clearly both in form and size from the typical patterns of the mithraea discovered until now in ancient Ostia. On the basis of the currently available data, a very late chronology (end of 4th century AD) can be proposed for the building.
\end{abstract}

Key words: Mithraism, ancient Ostia, Mithraeum of colored marbles, Roman religion, Caupona of god Pan

\section{MITHRAISM IN ITALY: SOME METHODOLOGICAL PROBLEMS}

For an overview of Mithraism in Italy, it is necessary to go back even now to the basic corpus of Maarten J. Vermaseren, elaborated in the middle of the $1950 \mathrm{~s}^{2}$ More recently an attempt to classify the structures was made in the Thesaurus cultus et rituum antiquorum. ${ }^{3}$ In the 603 Mithraic elements (which comprise objects and monuments) classified by M. J. Vermaseren, as opposed to the 36 buildings of the Thesaurus, a work which already belongs to our century. In reality, the frame is much more nebulous, and we only can offer some general remarks on Rome ${ }^{4}$ and

\footnotetext{
${ }^{1}$ Translated from French by Patricia A. Johnston.

${ }^{2}$ VERMASEREN, M. J.: Corpus inscriptionum et monumentorum religionis Mithriacae. 2 vols. The Hague, 1956-1960 [CIMRM].

${ }^{3}$ Thesaurus cultus et rituum antiquorum [ThesCRA] IV, Los Angeles 2005.

${ }^{4}$ PAVIA, C.: Roma mitraica. Udine 1986. For the case of Rome, I started recently to study some urban mithraea, as the Barberini Mithraeum, on which Alessandro Melega is currently working.
} 


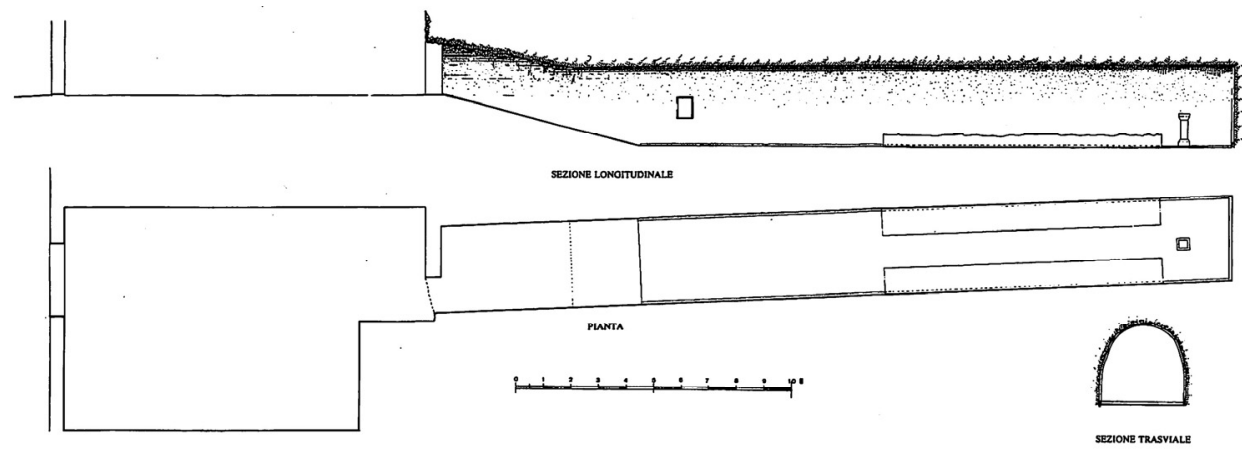

Fig. 1. Marino (Rome), Mithraeum, plan (according to Vermaseren)

Ostia, ${ }^{5}$ two towns where one can better recognize the large diffusion of the phenomenon. Mithraism is normally attested in urban centers, but also in the suburbs.

Among the rural centers, the case of the small village of Marino stands alone, where the presence of a mithraeum is documented in one abandoned quarry. ${ }^{6}$ At Marino (fig. 1), as in many other cases, the distributions of the rooms which flank the spelaeum have been little studied. Always characterized by an oblong plan (rarely quadrangular) and by a level bottom or with one apse, the spelaeum, with these rooms, formed the "system" of the Mithraeum: these rooms were in effect essential for the rituals and the needs of the community: apparatoria (dressing rooms), rooms for the initiation of the members, sacristies, kitchens, etc. ${ }^{7}$ These mithraea were formed in general by some built structures, and they are very rarely lodged in rocky sites, on the contrary as it was often believed.

Mithraism is a transversal phenomenon, which implicates every sector of the masculine population, but also the feminine, ${ }^{8}$ as certain witnesses seem to indicate, especially a graffito of the Mithraeum of Marino. ${ }^{9}$ Moreover, the presence in Italy of mithraea before the dynasty of the Severans weakens the cliche that places the phenomenon in the military sphere (no legion or armed cohort was installed in Italy before Septimius Severus, with the exception of special units such as the Praetorians).

${ }^{5}$ White, M.: The Changing Face of Mithraism at Ostia: Archaeology, Art and the Urban Landscape. In BALCH, D. - WeISSENRIEDER, A. (eds): Contested Spaces. Houses and Temples in Roman Antiquity and the New Testament. Tübingen 2012, 435-492.

${ }^{6}$ Vermaseren, M. J.: Mithriaca III. The Mithraeum at Marino. Leiden 1982 [EPRO 16]; RoCCO, G.: Attestazioni di culti e rinvenimenti di antichità orientali tra le vie Appia e Latina nel territorio di Bovillae e Castrimoenium. Horti Hesperidum. Studi di storia del collezionismo e della storiografia artistica 2.1 (2012) 601-637, here 612.

7 TURCAN, R.: Mithra et le Mithracisme. Paris 2004, $73 \mathrm{f}$.

${ }^{8}$ CIMRM II 1773 = CIL III 3415: Deo Arima/nio Libel/la leo / fratribus / voto /dic(avit). See SCARPI, P. (ed.): Le religioni dei misteri. Milano 2002, II 390; CHALUPA, A.: Hyenas or Lionesses? Mithraism and Women in the Religious World of the Late Antiquity. Religio 13 (2005) 199-230; DAVID, J.: The Exclusion of Women in the Mithraic Mysteries: Ancient or Modern? Numen 47 (2000) 121-141.

${ }^{9}$ Bedetti, A. - Granino Cecere, M.G.: Il Mitreo di Marino. Recenti acquisizioni. In GHINI, G. MARI, Z. (eds): Lazio e Sabina 9. Atti del convegno, Roma 2012. Roma 2013, 235-241. 
For Northern Italy, following the inclusion in the corpus of Franz Cumont, ${ }^{10}$ is based the suggestion which seeks to identify a Mithraeum in the so-called Tana del lupo ("Lear of the wolf") of Angera (Varese, Lombardy). New research, beginning in 2009 with a project of the University of Bologna and continued with other verifications and analyses by Stefano De Togni, ${ }^{11}$ now permit some new considerations. This fragile hypothesis, born in the period of the first studies, has now been replaced by the hypothesis which recognizes in the site a space consecrated to the cult of the Nymphs, perhaps linked to the presence of some neighboring quarries of dolomite stone. Nevertheless, there are also some reasons - in particular on the basis of an epigraphic testimony - which suggest the presence of a Mithraeum in the village. The case of Angera has an essentially methodological importance, in putting in evidence the attention and the precautions to take in the study of Mithraism. It is therefore always necessary to distinguish the weight and the signification of the archeological proof.

\section{THE CASE OF OSTIA}

According to the materials available and the dated monuments, the presence of Mithraism in Italy extends between the 1st and 4th centuries AD. At Ostia the greatest number of mithraea have been found in an urban setting. This case, thanks to the numerous discoveries made over several centuries, permits us to analyze closely the importance of the phenomenon between the age of Antoninus Pious and the age of Constantine. In the town, which in the 3rd century covered an area of 130 hectares, with a population calculated at 60,000 inhabitants, at least 15 mithraea are known (fig. 2), and the phenomenon, popular among the different social levels, grew, up to the end of the 4 th century. ${ }^{12}$

The only systematic and analytical study of the mithraea of Ostia remains that of Giovanni Becatti, published in 1954 in a series devoted to the excavations of the town, ${ }^{13}$ today to consult with the help of the precious updated observations by Michael White. ${ }^{14}$

${ }^{10}$ CuMONT, F.: Textes et monuments figurés relatifs aux mystères de Mithra I-II. Bruxelles 1896-1899.

${ }^{11}$ David, M. - DE TOGNI, S.: Angera (VA), Tana del lupo. Nuove ricerche. Notiziario della Soprintendenza archeologica della Lombardia 2008-2009. Milano 2011, 239-241; DAVID, M.: La Tarda Antichità nel territorio varesino. In HARARI, M. (ed.): Il territorio di Varese in età romana. Varese 2014, 172-195; DE TOGNI, S.: Siti santuariali di epoca romana in ambiente rupestre. Il caso della Tana del Lupo di Angera. Sibrium 31 (2017) 193-211.

${ }^{12}$ Clauss, M.: Cultores Mithrae. Die Anhängerschaft des Mithras-Kultes. Stuttgart 1992, 32-42 ; VAN HAEPEREN, F.: Pour une prosopographie des dévots d'Ostie: dédicaces collectives offrandes pour une collectivité. In BENOIST, S. - HoËT-VAN CAUWENBERGHE, CH. (éds): La vie des autres. Histoire, prosopographie, biographie dans l'Empire romain. Lille 2013, 151-166.

${ }^{13}$ BeCATTI, G.: Scavi di Ostia. II: I mitrei. Roma 1954; Floriani SQuARCIAPINO, M.: I culti orientali a Ostia. Leiden 1962; LAEuCHLI, S. (ed.): Mithraism in Ostia. Mystery Religion and Christianity in the Ancient Port of Rome. Evanston 1967; BAKKER, J.-TH.: Living and Working with the Gods. Studies of Evidence for Private Religion and Its Material Environment in the City of Ostia (100-500 AD). Amsterdam 1994.

${ }^{14}$ WHiTE (n. 4). 


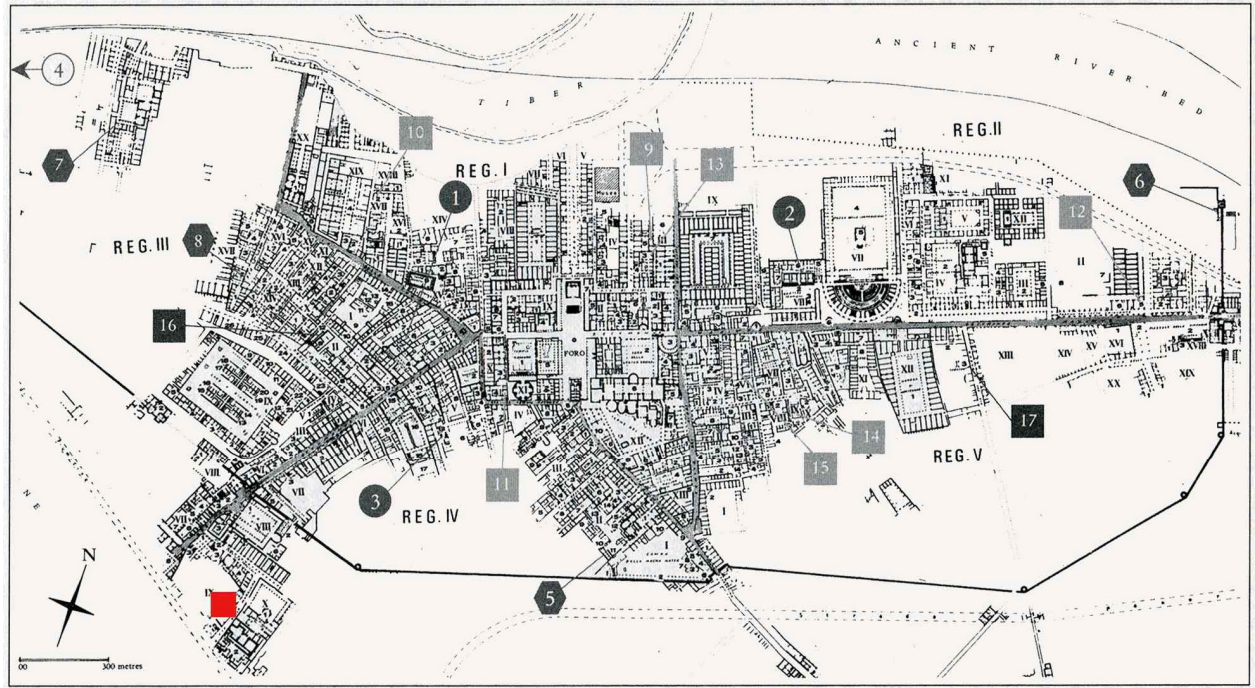

Fig. 2. Ostia. Plan of the city, with the position of the Mithraea.

Down on the left side, the Mithraeum of colored marbles, in the district "outside Porta Marina"

In the new chronological order established by White, in the Antonine period are placed the Mithraea "of the painted walls", "of the seven spheres" and "of the seven doors"; in the Severan period the Mithraeum Fagan, that one "of animals", Aldobrandini, of the Imperial Palace, of the "planta pedis"; in the first half of the 3rd century, the Mithraea of Lucretius Menander and of the Baths of Mithras; in the second half of the 3rd century, the Mithraea of Fructuosus, of the Porta Romana, of the House of Diana, of Felicissimus and of the Snakes.

At Ostia one clearly sees the archeological traces of the violent destruction of mithraea made by the fanatical fringe of the rising Christian wave ${ }^{15}$ and up to now no rising mithraeum in the 4 th century has been identified.

\section{THE "MITHRAEUM OF COLORED MARBLES"}

In the course of research conducted from the beginning of 2007 by the Ostia Marina Project - a project of the Department of History and Cultures of the University of Bologna with the "Ministero dei Beni e delle Attività Culturali e del Turismo" some new subjects of reflection have emerged concerning the development of the city of Ostia, and in particular concerning its suburbs. The portion outside of Porta

${ }^{15}$ TURCAN, R.: Les motivations de l'intolerance chrétienne et la fin du mithriacisme au IV ${ }^{\mathrm{e}}$ siècle apr. J.-C. In Actes di VIIe Congrès de la Fédération internationale des études classiques. Budapest 1983, II 209-226 (= ID.: Recherches mithriaques. Paris 2016, 109-134). 


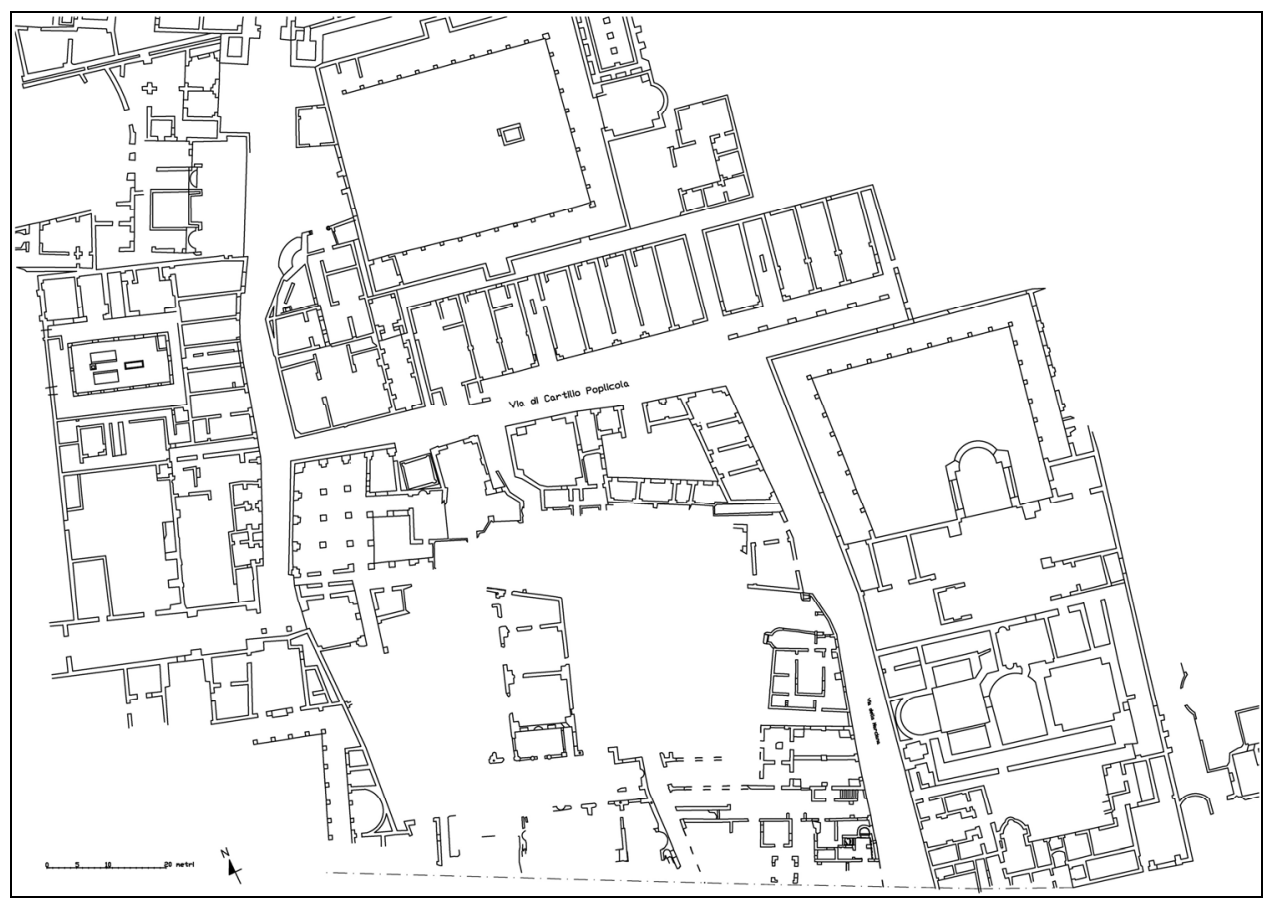

Fig. 3. Ostia, Insula IV, ix. Plan

Marina ("fuori porta Marina") ${ }^{16}$ was developed in an environmental frame characterised by the very dynamic movements of the coastline (fig. 3 ). In the 2 nd century AD the city attained a special condition of equilibrium with the sea, thanks to the transformation, in the Severan age, of the original coastal track in a paved route furnished also with a series of thermal baths arranged along its north side. ${ }^{17}$ The presence of these structures favored the development of a polymorphic tertiary that attracted clients night and day.

Along the via della Marciana, a street flanking the Baths of Porta Marina connected to the Severan route, commercial and public sites of different types mingled. In the age of the Severans, a small caupona (tavern) at ground level of the "Building of Two Staircases" closes its doors (fig. 4). Perhaps, because of this closure, a building able to serve clients through the day and night had been conceived and constructed. It is this building - characterised by an elegant opus listatum - of about 180 square

${ }^{16}$ VALERI, C.: Brevi note sulle Terme di Porta Marina a Ostia. Archeologia Classica 52 (2001) 307-322; OrofinO, G. - TURCI, M.: Analytical investigations in Ostia: Porta Marina (Rome). In MACCHIA, A. - Greco, E. - ChiarandÀ, B. A. - BARBABietola, N. (eds): YOCOCU. Contributions and Role of Youth in Conservation of Cultural Heritage. Rome 2011, 393-402.

${ }^{17}$ BRANDIZZI VITUCCI, P.: Considerazioni sulla Via Severiana e sulla Tabula Peutingeriana. MEFRA 110 (1998) 929-993. 


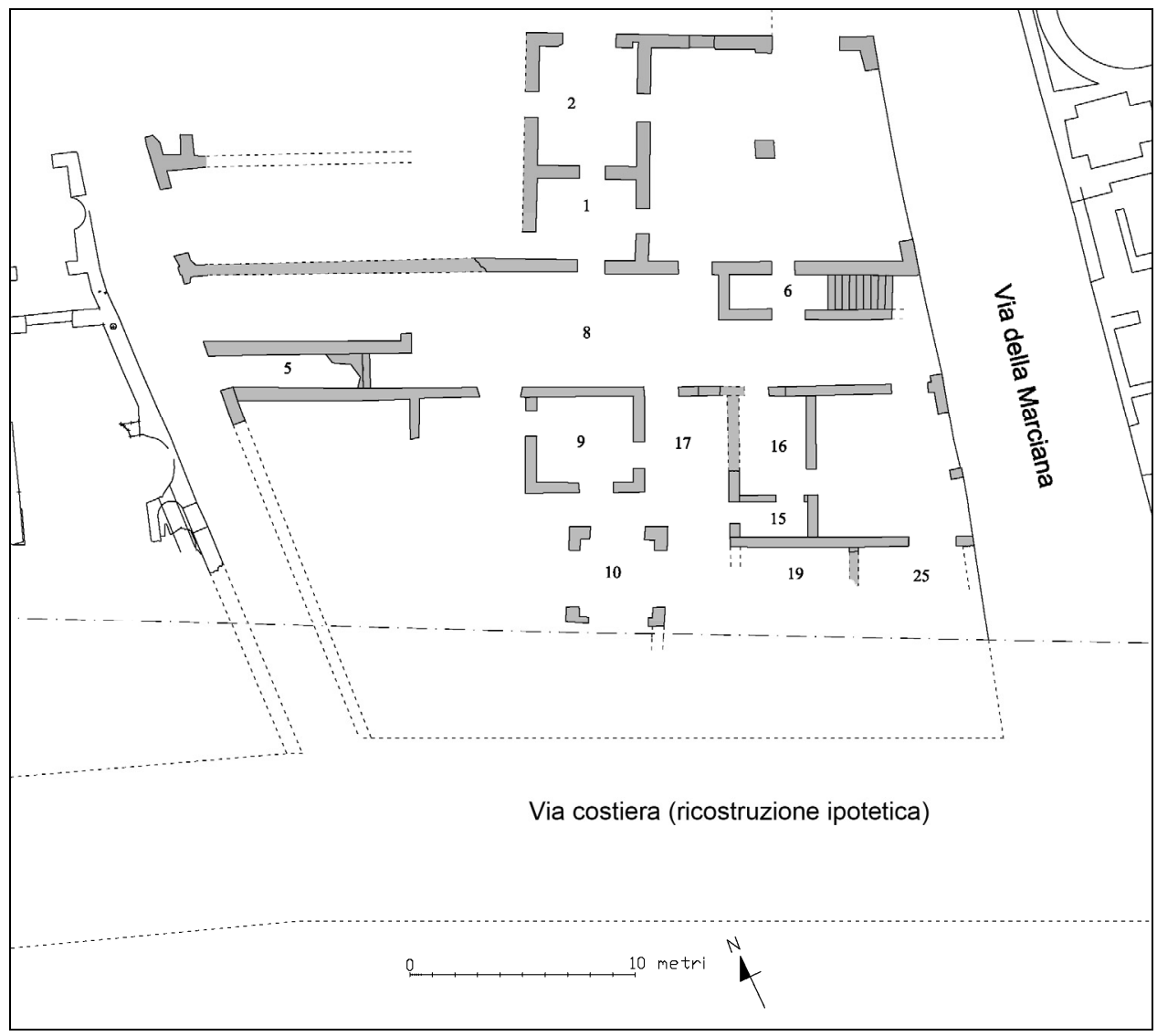

Fig. 4. Ostia, Plan of the Building of two Staircases (M. David - S. De Togni)

meters, which we have named "Caupona of the god Pan""18 because of the subject of the mosaic pavement of the main room (figs 5-6). ${ }^{19}$ The spaces were reset in a rational way among those used by the clients, those for the staff and those reserved for the exclusive use of the owners.

An isometric reconstruction of the caupona shows the characteristics of a building conceived as a caupona/popina (tavern/restaurant) - that is a wine shop with some snacks - for the residents and for the travellers on the Severan route. ${ }^{20}$ One must consider the hypothesis that this caupona also had a secondary function, reserved for

${ }^{18}$ DAVID, M.: Una Caupona tardoantica e un nuovo mitreo nel suburbio di Porta Marina a Ostia antica. Temporis Signa 9 (2014) 31-44.

${ }^{19}$ DAVID, M.: Nuovi mosaici pavimentali dalla Caupona del dio Pan a Ostia antica. In ANGELELLI, C. - MASSARA, D. - SpOsITO, F. (edd): Atti del XXI colloquio dell'Associazione italiana per lo studio e la conservazione del mosaico, Reggio Emilia, 18-21 marzo 2015. Tivoli 2016, 359-367 (with S. De Togni, G. P. Milani, A. Pellegrino, J. Ferrandis Montesinos, M. Carinci).

${ }^{20}$ Hermansen, G.: Ostia. Aspects of Roman City Life. Alberta 1982. 


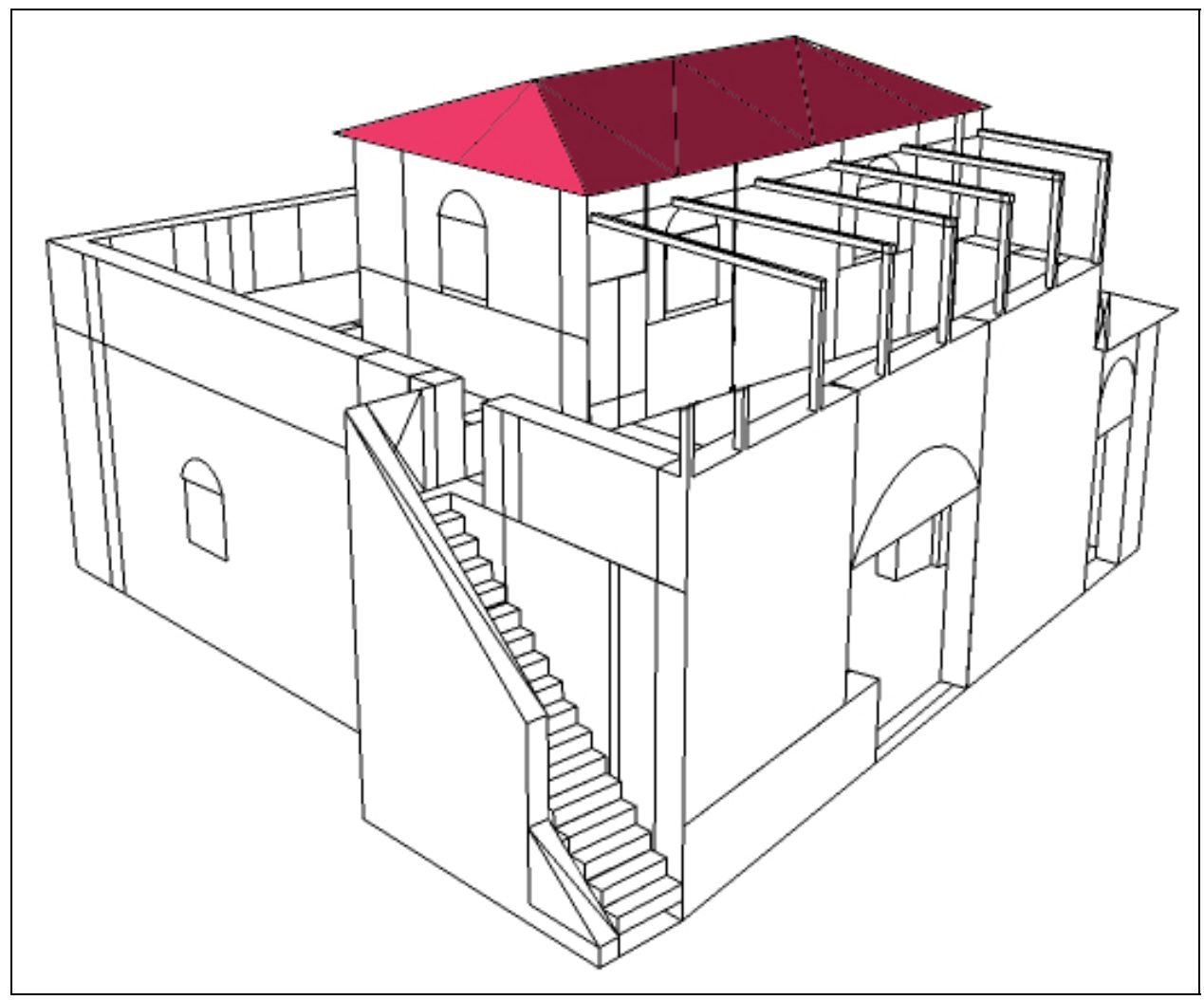

Fig. 5. Hypothetical reconstruction of the Caupona of god Pan (S. De Togni)

religious celebrations, that of receiving the worshippers of Mithras. Stratigraphic analysis has shown in effect that room no. 1 - a basement - would originally have had a mosaic pavement and would have been independently accessible from other parts of the caupona. After about a century of activity, in the second half of the 4th century $\mathrm{AD}$ the caupona would change its function: the main entrance was closed, other doorways were modified and the painted decoration of the walls was entirely renewed (with the imitation of marble slabs). The building in fact came under a religious sect and in room no. 1 the spelaeum of the Mithraeum was arranged. So the whole building has been named by us the "Mithraeum of colored marbles".

The reorganization of the interior spaces has led to a transformation of zones of service (room no. 6), perhaps as a depository; the central room of the caupona and rooms no. 5,7 , and 8 took on a complementary role, with regard to the spelaeum

${ }^{21}$ DAVID, M.: Il pavimento del nuovo Mitreo dei marmi colorati a Ostia antica. In ANGELELLIMASSARA-Sposito (n. 19) 369-376 (with D. Abate, S. De Togni, M.S. Graziano, D. Lombardo, A. Melega, A. Pellegrino). 


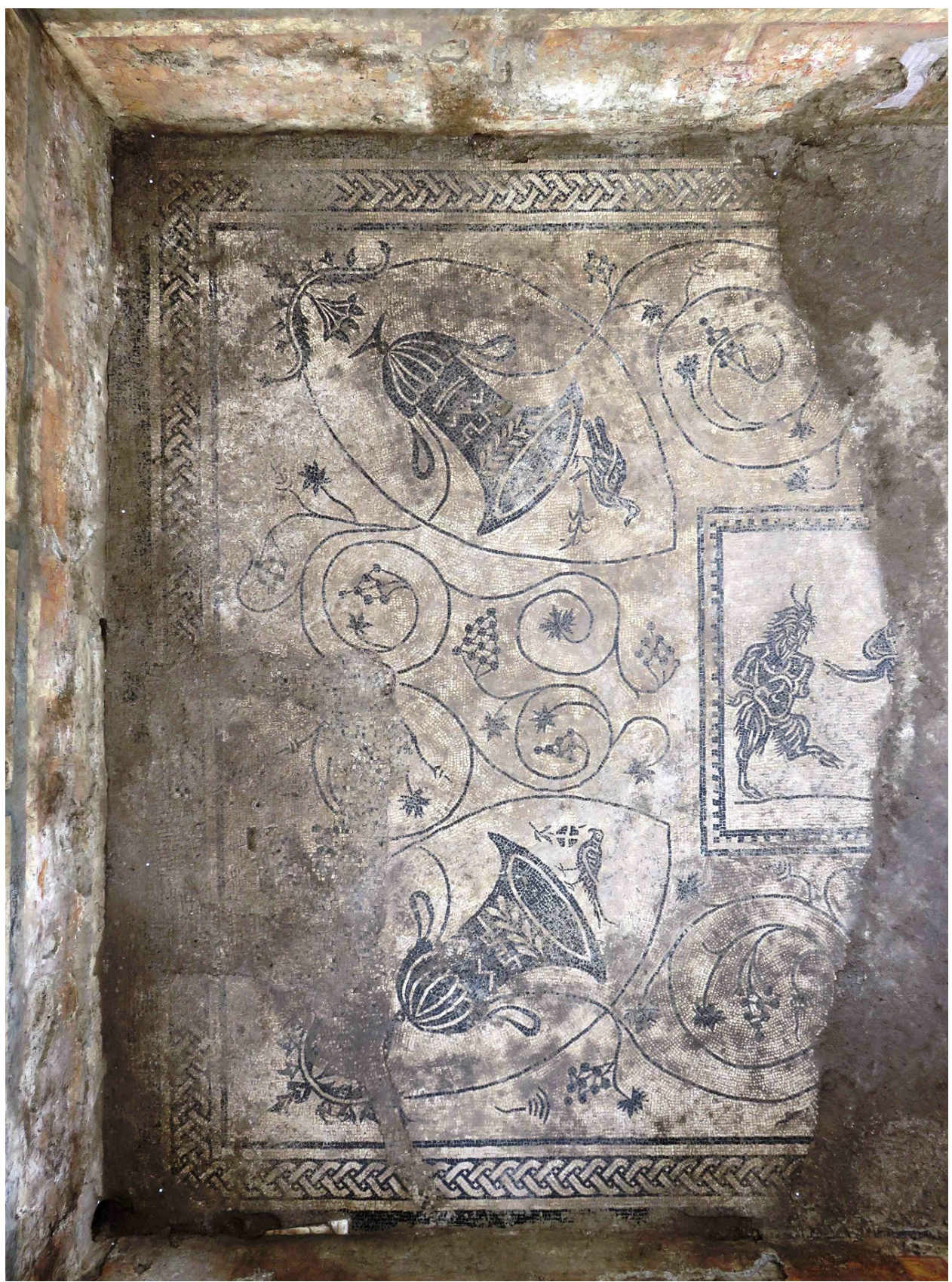

Fig. 6. Ostia, Caupona of god Pan. Zenital view of the mosaic floor with the "fight of the god Pan" (S. De Togni) 
(no. 1), where the liturgical functions of the sacrifice and of the ritual banquet (fig. 7) are concentrated. ${ }^{22}$

In one of the secondary rooms (no. 8), decorative elements of symbolic worth and of great interest have been identified; on the pedestal, painted in red on deep yellow, a "trident", alternating with arrows, is repeated several times (fig. 8). The motif of the trident is linked to the tradition of Roman painting, but in this case it probably plays a particular meaning in the Mithraic theology. In fact, as it is known, the god himself was an archer and was accompanied by Cautes and Cautopates, who were also archers. For the moment, the most reasonable hypothesis is therefore that this is a reflection of the trinitarian nature of the main divinity of Mithraism. The relief of Dieburg in Germany (fig. 9), with the representation of a tree with three branches terminating with three heads, is a clear allusion to the trinitarian concept of God (as confirmed by Pseudo-Dionysius the Areopagite). ${ }^{23}$

In the context of this arrangement, room no. 7 was enlarged up to the corridor. The decoration of the walls of this room is characterised by a yellow pedestal, as in the other rooms, but the median zone - separated by a red band - is strewn with rosebuds on a white background, according to a well known fashion of the 4th century.

In the apse of the spelaeum, there was a rectangular niche, and in the nave two altars, a single podium, a small bed of flowers, and a ritual well in marble. The furniture, perhaps in wood, was mobile (fig. 10). It is utterly a space totally different in regard to mithraea known up to this time at Ostia, which in their turn are representative of the complexity and of the variety of Mithraist architectural experiences in the Roman world. The difference is linked principally to the very limited space, ${ }^{24}$ to the presence of a single bench and to the particularities of the pavement, comparable with those known from the 5 th century (in Sicily, for example).

For a correct interpretation of this complex, it is necessary to take into consideration many other indicators, like the graffiti on the walls of the central room (no. 3), which refer to the religious world of Mithras. First, on the west wall, a clearly legible single name is written: Concordius, a name quite wide-spread starting from the 4th century, mostly in Christian epigraphy, when the Roman system of first names had been reduced to a single element, expecially for persons in a non-servile condition. Under the name Concordius, other letters have been traced, of much greater hight, displaced toward the center of the epigraphic field: Inv(icto) D(eo) (arrow) $M$ (ithrae) (bow with an arrow) $D(e o) M(a g n o)$ Kro=no ("to the unconquered god Mithras and to the great god Kronos") (fig. 11).

${ }^{22}$ DAVID, M.: Osservazioni sul banchetto rituale mitraico a partire dal Mitreo dei marmi colorati di Ostia antica. In CuSCITO, G. (ed.): L'alimentazione nell'Antichità. Atti della XLVI settimana di studi aquileiesi. Aquileia, 14-16 maggio 2015 [Antichità Altoadriatiche 84]. Trieste 2016, 173-184.

${ }^{23}$ Ps. Dyon. Epist. 7. 2.

${ }^{24}$ See for example the Mithraeum of Hawarte, Syrie; GAWLIKOWSKI, M.: Hawarti. Preliminary Report. Polish Archaeology in the Mediterranean 10 (1998) 197-204; ID.: Un nouveau mithraeum récemment découvert à Huarté près d'Apamée (information). Comptes rendus des séances de l'Académie des Inscriptions et Belles-Lettres 144.1 (2000) 161-171; ID.: The Mithraeum at Hawarte and Its Paintings. JRA 20 (2007) 337-361. 


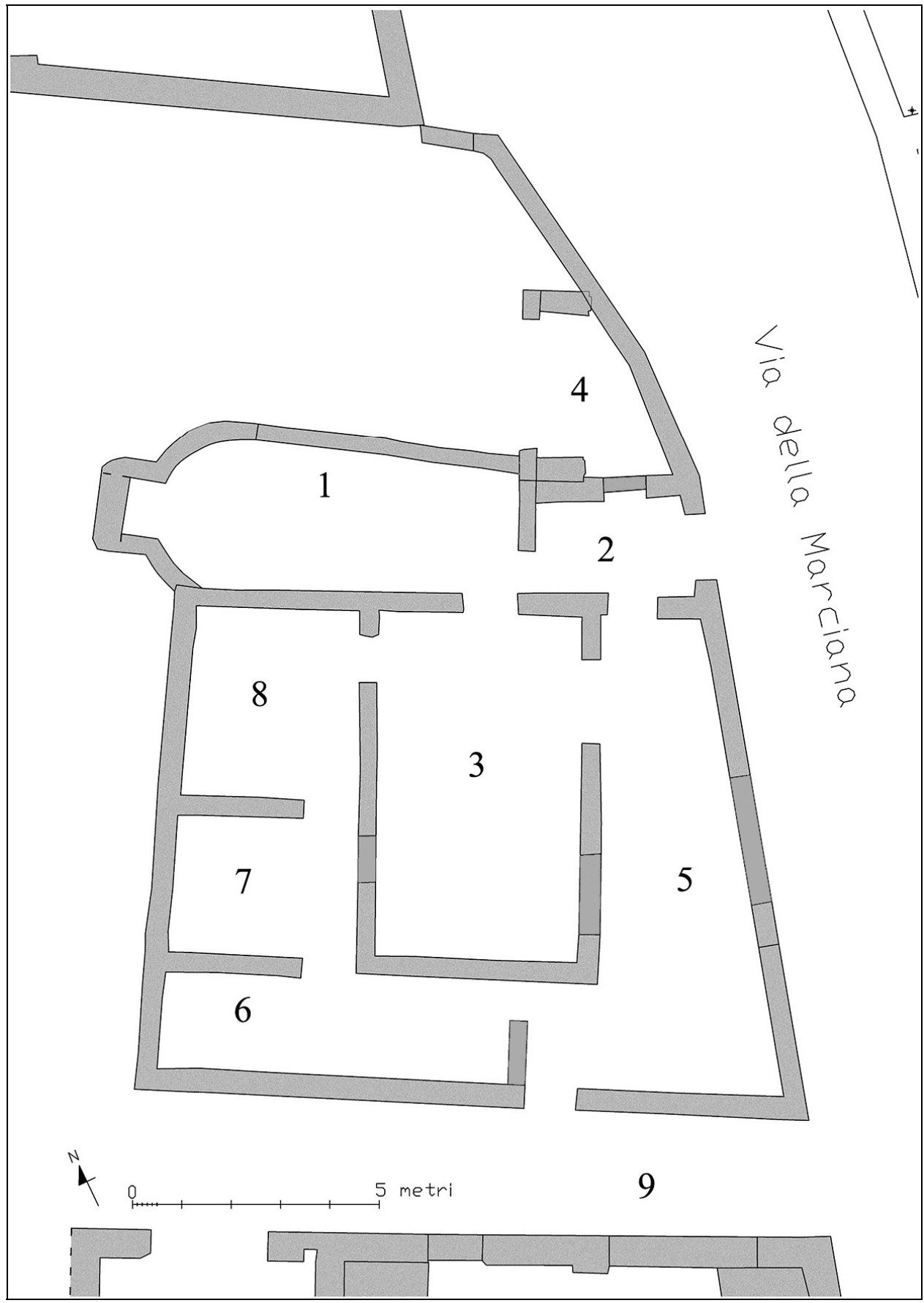

Fig. 7. Ostia, Mithraeum of the colored marbles. Plan (M. David - S. De Togni) 


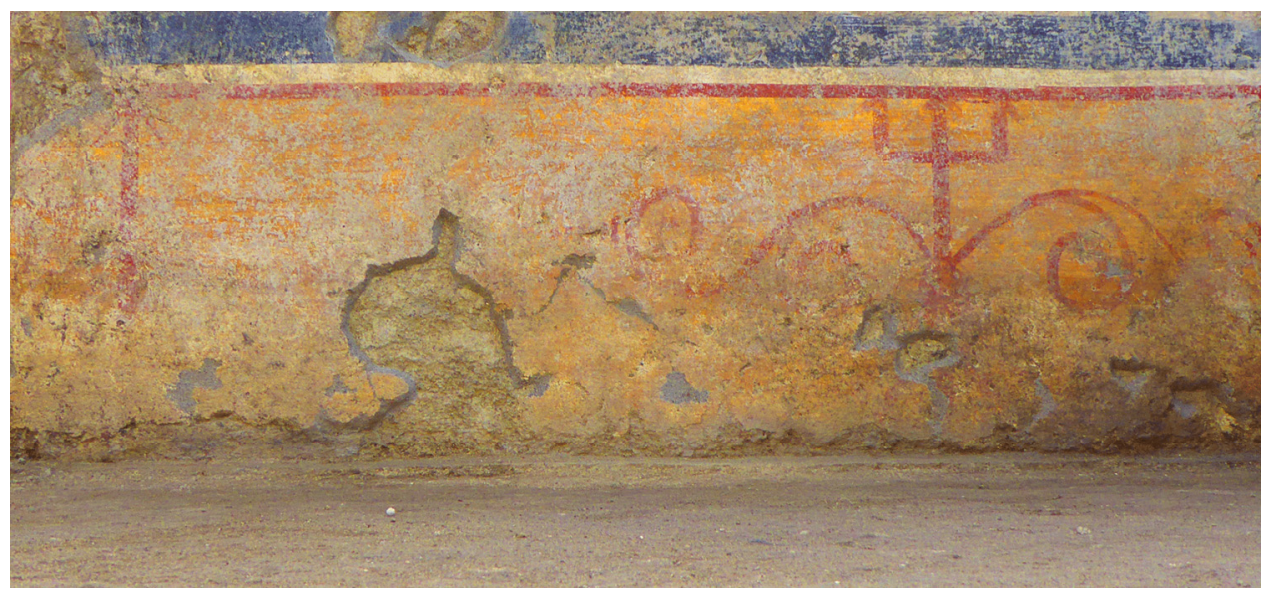

Fig. 8. Ostia, Mithraeum of the colored marbles, pedestal of room no. 8 with painted decoration of tridents

It is suitable to underline that here it is not the god Mithras alone who is named, but also the god Kronos, a divinity of the Mithraic Pantheon frequently mentioned in literary sources. ${ }^{25}$ The ancient authors seem to agree that Kronos corresponds to the Roman god Saturnus. It is certainly not a case that the dies natalis of Mithras is situated immediately after the Saturnalia (December 17-23); moreover, it is suitable to note that the seventh and the highest degree of initiation of Mithraism, i.e. pater, was placed under the protection of Saturnus.

In the same room, on the south wall, some monograms with Mithraic characteristics were also found. ${ }^{26}$

Another point to note is the presence of the very small bed of flowers, where analyses of pollen have shown traces of Juniper, an essence completely foreign to Ostia; this is known to be a sacred plant in the Persian world, particularly utilized in certain religious practices.

In modern times (from the 15 th to the 17 th century) the activity of organized teams of exploiters, who pillaged every residual trace of marbles or of precious metals, produced the effect of mingling layers. Some objects of a particular nature offer moreover some grounds for reflection on the confluence, the acceptance and the coexistence of different religious expressions in the building. I refer in particular to some objects in jet (a black stone, connected perhaps to followers of the cult of Cybele) and to a small Isiac crown in bronze; it is necessary to add to these the graffito of the navigium Isidis on the wall of room no. 3 (fig. 12). The most important discovery, which seems to serve as a bridge between the followers of Mithras and of Isis, ${ }^{27}$ is an [EPRO 109].

${ }^{25}$ BECK, R.: Planetary Gods and Planetary Orders in the Mysteries of Mithras. Leiden 1988

${ }^{26}$ See in the contribution of M. David and A. Melega in this Volume, DOI: 0.1556/068.2018.58.1-4.8.

${ }^{27}$ VAN HAEPEREN, F.: Cohabitation or Competition in Ostia under the Empire? In ENGELS, D. VAn Nuffelen, P. (eds): Religion and Competition in Antiquity. Bruxelles 2014, 133-148. 


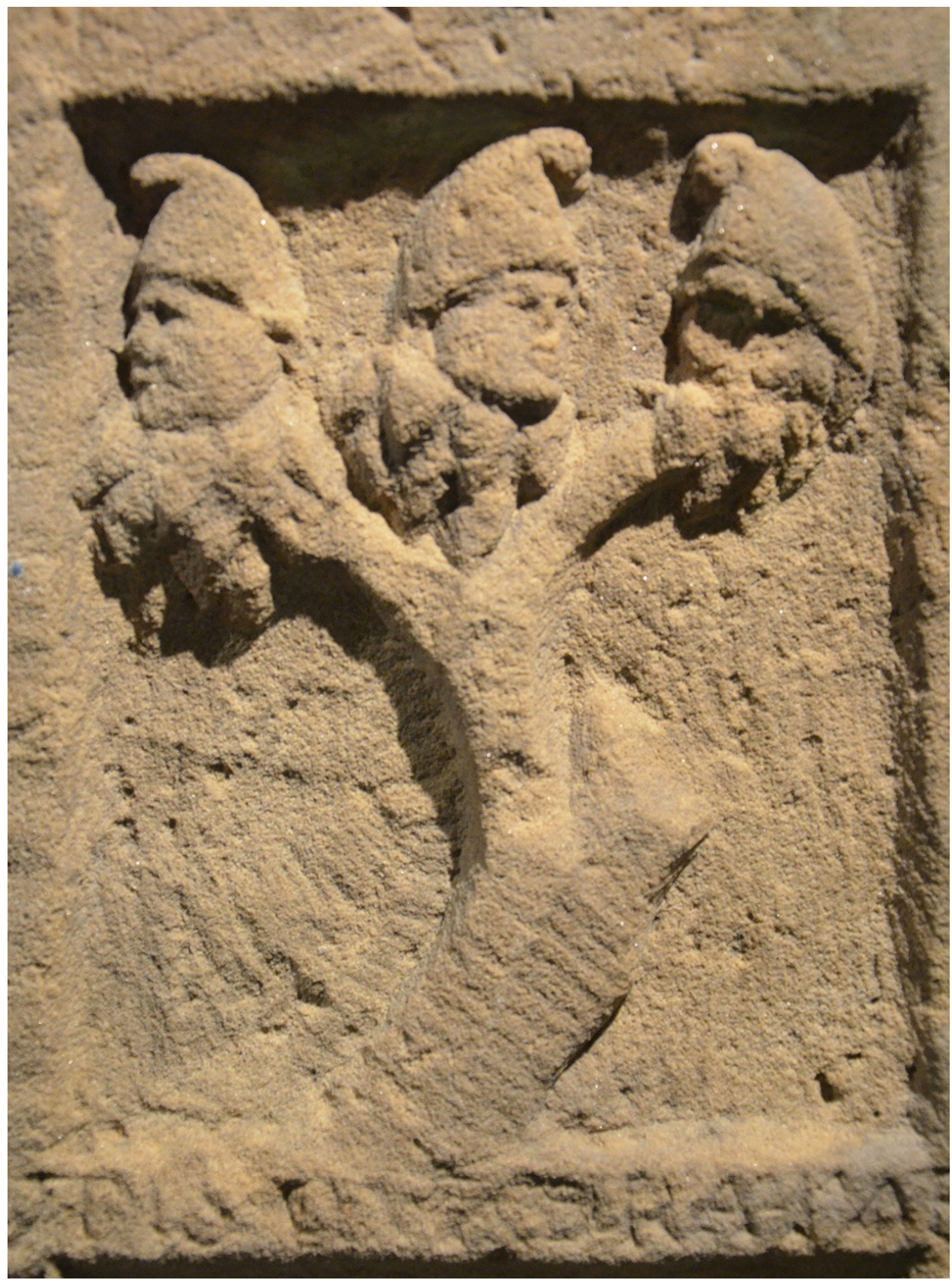

Fig. 9. Dieburg, Museum Schloss Fechenbach (Germany), Mithraic relief with a tree with three heads 


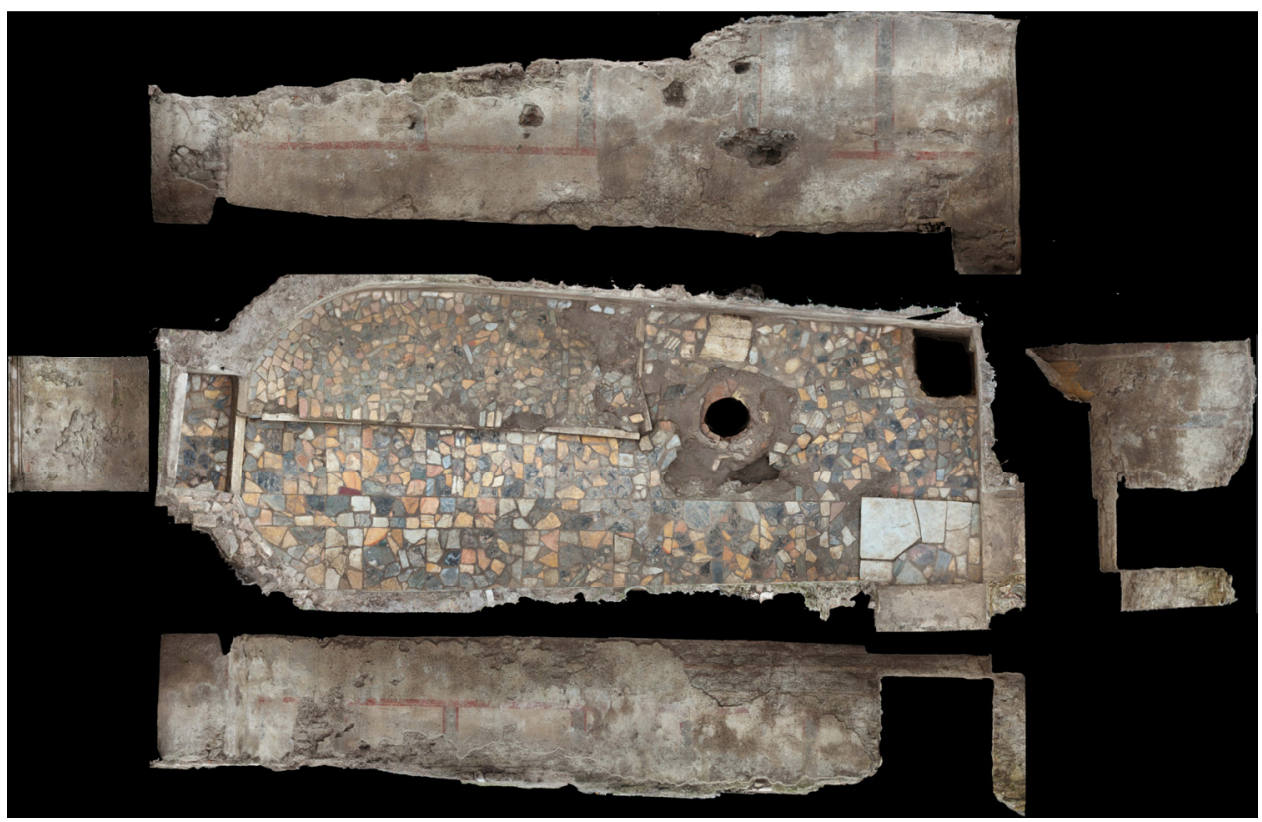

Fig. 10. Ostia, Mithraeum of colored marbles. Relief by Laser scanner (D. Abate)

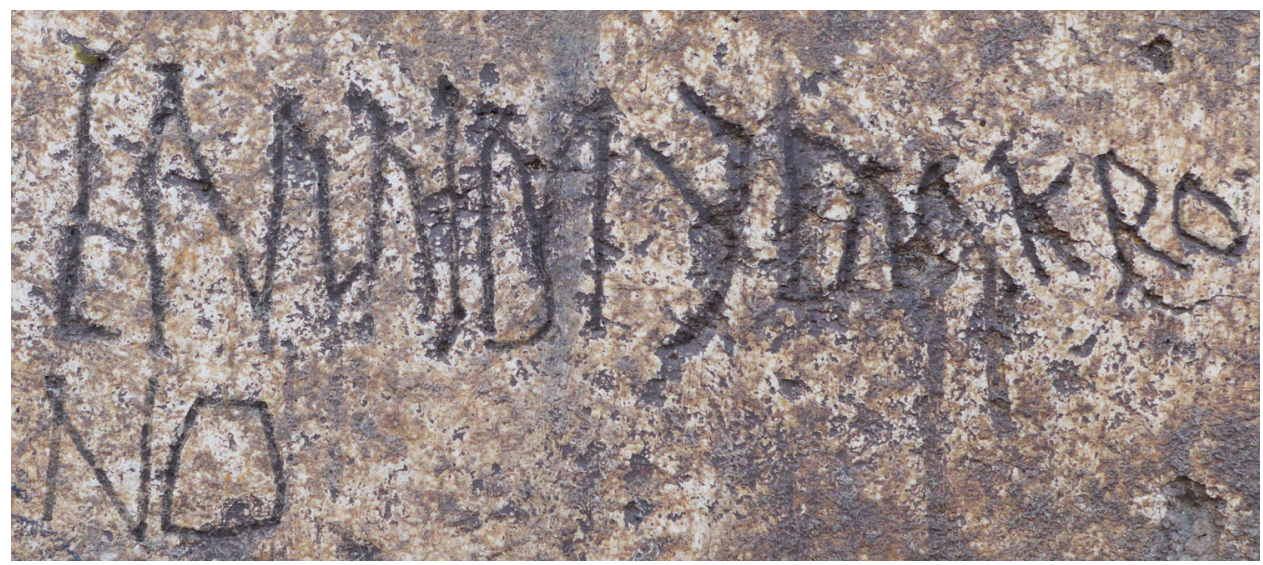

Fig. 11. Ostia, Mithraeum of colored marbles, room no. 3, graffito with the names of Mithras and Kronos

ivory handle, probably a ritual instrument, perhaps a sistrum, an object of Egyptian origin, but well known in the world of Mithras (fig. 13). It is, for example, associated with the grade of the lion on the mosaic pavement of the Mithraeum of Felicissimus.

The chronological problems which this new building shows cannot be further resolved. To what period does the rearrangement of the apsed room refer? Is it perhaps the result of large floods of the river Tiber, which literary sources place in 374 and 398 ? Only research will help us to answer to these questions. 


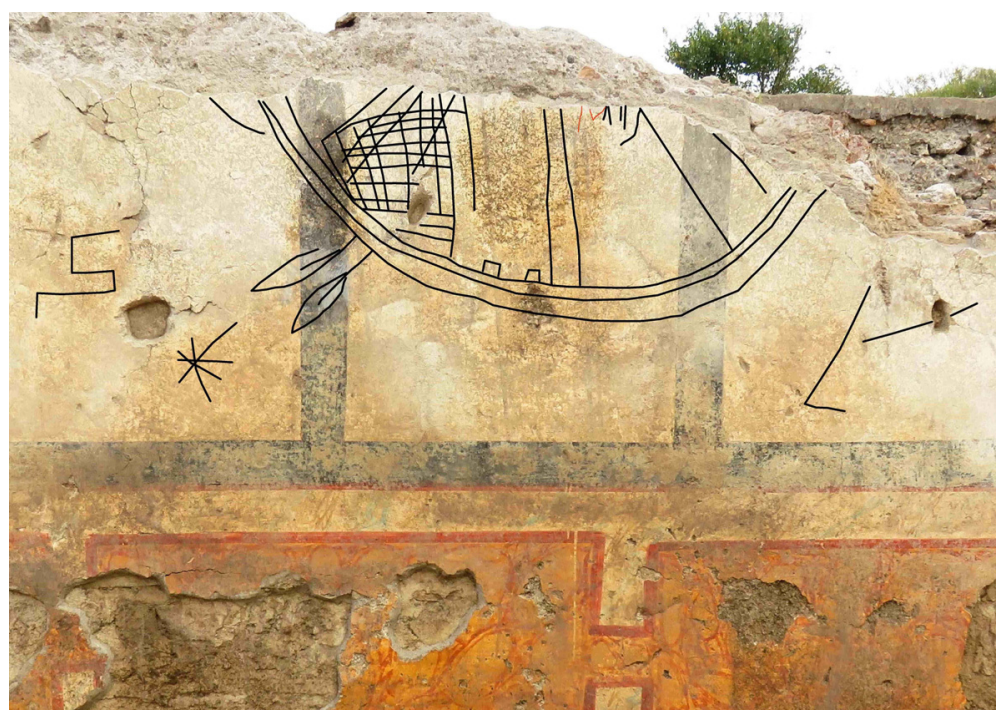

Fig. 12. Ostia, Mithraeum of colored marbles, room no. 3, graffito with "Navigium Isidis"

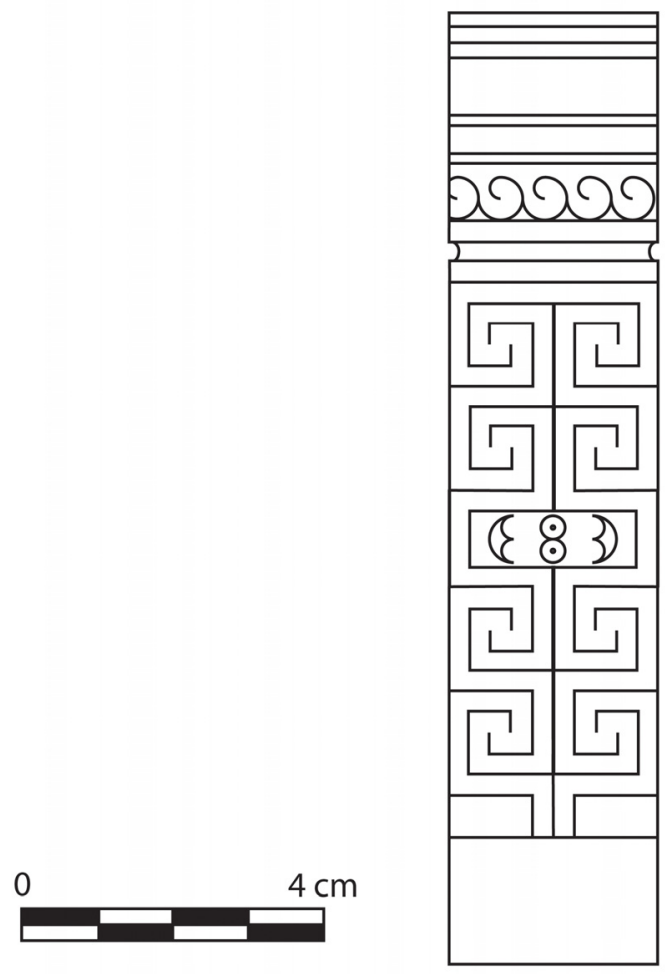

Fig. 13. Ostia, Mithraeum of colored marbles. Ivory handle of sistrum discovered during the excavation (A. Melega) 
The archaeological data indicate a short duration of the use of this building (even on the basis of the complete absence of traces of wear on the edge of the well). There is no proof of vandalism or of violent destruction, as in the case of the Mithraeum of the Baths of Mithras, the Mithraeum of Fructosus and the Mithraeum of the painted walls. There are moreover some acts of profanation, as it seems to indicate the closure of the ritual well. One can assume that a specialized workshop was charged to dismantle the building, leaving in evidence the figure of the god Pan, perhaps with the intent of revealing its diabolical value to the gaze of Christians. In the end the zone was walled up and forbidden to the public.

The interest of the complex evidently comes from its extreme delay, but also from its capacity of transmitting the image of a sector of the town which an inscription indicated as sordens, "sordid". In the end of the 4th century only the Baths of Marciana represented the past history of the district.

The Mithraeum of colored marbles - the only mithraeum excavated in the $s u b$ urbium of Ostia until now - offers the possibility of analyzing a religious complex of Mithras in its entirety, and not only, as often, in its better known form that is the room of the cult or the spelaeum. This invites us to continue the research on the gloomy paths of forbidden religions in the Empire, beyond the fateful date of the death of Theodosius (395 AD). In these years, Christianity at Ostia expanded very quickly in the entire town under the direction of the bishops who resided very near to the route of Sabatius, and Mithraism went into dissolution. ${ }^{28}$

\author{
Massimiliano David \\ Alma Mater Studiorum - University of Bologna \\ Italy \\ massimiliano.david@unibo.it \\ Sapienza University of Rome \\ Italy \\ maxvictor.david@uniroma1.it
}

${ }^{28}$ DAVID, M.: La fine dei mitrei ostiensi. Indizi ed evidenze. In PANAINO, A. - PIRAS, A. (edd): Proceedings of the 5th Conference of the Societas Iranologica Europaea 1. Ancient and Middle Iranian Studies, Ravenna, 6-11 ottobre 2003. Milano 2006, 395-397. 
